\title{
Teamwork as an interactive educational technology at pedagogical universi- ties
}

\author{
Natalia Volkova $^{1, *}$, Olha Lebid $^{1, * *}$, Olha Hrom $^{1, * * *}$, Nataliia Zinukova ${ }^{1,2, * * * *}$, and Tetiana Korobeinikova ${ }^{1, \dagger}$ \\ ${ }^{1}$ Alfred Nobel University, 18 Sicheslavska Naberezhna, Dnipro, 49000, Ukraine \\ ${ }^{2}$ Humanitas University in Sosnowiec, 43 Kilińskiego Str., 41-200 Sosnowiec, Poland
}

\begin{abstract}
A significant shift is taking place at higher educational institutions and emphasizes group or teamwork during the academic process. This article introduces incorporating teamwork into pedagogical courses. The application of the teamwork pedagogy is relevant due to a strong necessity to find a successful educational technology of professional teachers' competencies development required by the modern international labor market. Sufficient results have been achieved with the use of theoretical and empirical research methods as analysis, generalization, and systematization of scientific papers, observation, reflectivity, and social intelligence diagnosis, pedagogical modeling, questioning, and collecting data. The scientific novelty of the theoretical part is highlighted through the importance of applying teamwork as a more successful educational technology, proving effective tools, and strategies for designing the new teamwork-based educational process of master's degree students in Pedagogy. On the practical side, this new pedagogy has been applied in two universities, and it is concluded that teamwork can enhance problem-solving and creativity, generates understanding, support, commitment, acceptance, and bring out the best of the future university teacher.
\end{abstract}

\section{Introduction}

The need for a profound scientific research in the field of teamwork development is attributed to modern rapid socio-economic, innovative and educational transformations taking place in Ukraine, with the focus placed on young competitive staff who demonstrates both professional competencies and a number of communicative and personal qualities required by the labor market. Today, any modern university tries to implement various innovative projects in the academic process. So, there is a strong necessity to combine intellectual and cognitive efforts of university teachers to solve important educational problems. Therefore, these professionals should strive to cooperation, active participation in efficient pedagogical teams, where the members are characterized by cohesion, valueoriented unity, "coordinated positive synergy" (R. Abliazov et al [1]). Team members demonstrate their ability to work together, when a joint result is much higher than an individual one or, even, the sum of the results. They should have a developed sense of "we", be able to coordinate steps and actions in joint activities, maintain a high pace of work, understand and solve individual tasks to achieve a common goal by revealing their personal potential. Given the above, the training of future university teachers is closely linked with the search of new directions for the higher educational system's restructuring, in-

\footnotetext{
*e-mail: npvolkova@duan.edu.ua

**e-mail: swan_ov@ukr.net

***e-mail: olha.hrom@gmail.com

****e-mail: natzinukova@gmail.com

†e-mail: tikorobeinikova@gmail.com
}

cluding the active implementation of team-building technologies, flexible methods and forms of teamwork in the process of their professional training.

\section{Literature review}

This article begins with a short review of the literature regarding teamwork issue. The problems of the formation and development of different professional teams and groups are considered in national and foreign scientific papers. Theoretical foundations of team building technologies are covered in the works of R. Abliazov [1], R. Belbin [2], A. Ivleev [3], A. Kariakin [4], D. Shakirova [5] and others. A more comprehensive description of the problem of interpersonal interaction as the basis of team building can be found in the work of psychologists (V. Horbunova [6], L. Fox et al [7]), a component of a group theory (G. Satran [8], L. Tompson [9]). This problem is of central interest as much resent research in the works of sociologists who identify synergetic effects of the team interaction (T. Galkina [10], etc.).

A number of authors have recognized the problems of team building and its development (V. Okuniova [11], G. Satran [8], L. Tompson [9], K. Shakhmayeva and L. Savva [12], and others). Some authors have driven the further development of team roles (V. Avdeev [13], R. Belbin [2], A. Karyakin [4], A. Panfilova [14] and others). E. Salas, D. Reyes and S. McDaniel [15] developed the scientific concept of teamwork where the progress, reflection and perspectives of this method were elaborated. Various aspects of team activities and human behavior in a team are 
revealed in the works of L. Aksenovska [16], A. Horbovyi [17], S. Tannenbaum, R. Beard, E. Salas [18], S. SchinkoFischli [19] and others. The problem of teambuilding model which combines business and educational learning concepts attracted attention of some researchers as P. Lau, T. Kwong, K. Chrong, E. Wong [20] and A. Doyle [21], who underlined the difference in the use of teams in business class settings compared to teams in educational class settings.

Most early studies as well as current work focus on teachers' team building work, which was the subject of the research carried by L. Karamushka [22], O. Fil [23] and others. While business and education share a common theoretical base, the implementation of the methods and techniques regarding teamwork are different. According to these approaches, there is no unified team model, but team members seem to work better when they are cooperating with each other. Therefore, the need for teambuilding methods in educational setting that combine task delivery with developing teambuilding skills seems evident.

Simultaneously the problem of teambuilding activities in the classroom can be used to weave together various experiences, contents, and viewpoints to promote communication, collaboration and respect. The issue of different activities that promote trust and build relationships by creating a respectful environment in which the participants can contribute at their individual levels of comfort was of interest of K. Greene in her research [24].

M. Loughry, M. Ohland and D. Woer elaborated the list of team skills and related interpersonal competences among which were the ability to work in diverse, multicultural environment, to think reflectively about the relationships between the students, underlying their importance and their value for future employers [25].

The problem of teambuilding development and teambuilding skills in college students was of interest of S. Marasi [26] and P. Lau, K. Kwong, K. Chong and E. Wong [20]. Teaching inter professional teamwork skills to health professional students was in focus of L. Fox, R. Onders, C. J. Hermansen-Kobulnicky, T. Nguyen, L. Myran, B. Linn and J. Hornecker [7]. B. Sairam, C. Sirisuthi and K. Wisetrinthong [27] in their findings showed that teambuilding leadership skills enhancement program have five toolkits, applying which the primary school administrators could manage their teamwork more efficiently and the overall progress of team building could become more successful.

To add more, the next step to the development evaluation system is the problem of assessment of teambuilding skills. The recent works of X. Zhuang, C. MacCann, L. Wang, L. Liu and R. Roberts [28] show the research results of the development and validity evidence supporting teamwork and collaboration assessment for high school students. Using such an approach to the problem of assessment E. Britton, N. Simper, A. Leger and J. Stephenson [29] developed a measurement tool to evaluate individual teamwork skills at higher school.

The current global pandemics has also been reflected in scientific investigations and the group of researchers C. Chakraborty, A. Sharma, G. Sharma, M. Bhattacharya,
R. Saha and S. Lee highlighted the importance of developing extensive partnership, collaboration and teamwork in academic settings to stop COVID-19 outbreak [30].

Although studies have been conducted by numerous authors, the problem of competence development of future university teachers' team interaction in the process of master's degree students' training is still insufficiently explored.

\section{Research methods}

To achieve the goal of the article, a set of qualitative and quantitative research methods was applied: theoretical analysis, generalization and systematization of scientific data in order to develop theoretical foundations for the development of teamwork interaction competence of the future university teachers in the process of master's degree students' training; empirical: the method of "Need for Communication", the questionnaire of interpersonal relations, value scale method "Self-actualization test"; ratio competence diagnostics of knowledge acquisition and knowledge acquisition strength; observations, analytical maps of the level of team interaction skills, a questionnaire to determine team roles (R. Belbin [2]); methods of social intelligence diagnosis, empathy diagnosis method; methods of reflectivity diagnosis; pedagogical experiment (diagnostic, forming, controlling stages) in order to determine the efficiency of the target competence in the process of teamwork development among future university teachers during master's degree students' training.

Empirical data were collected at Alfred Nobel University (Dnipro), Classical Private University (Zaporizhzhya), Kremenchuk Mykhailo Ostrohradskyi National University (during 2018-2020), 16 staff members of the universities mentioned above and 154 Master's degree students who are obtaining second level (Master's degree) in the educational-professional program Pedagogy of higher education establishment in specialty 011 Educational, Pedagogical sciences participated in the experiment.

\section{Results and discussion}

Our research aims at finding a solution for this challenging problem. There is a clear conviction that team building is the basis for the development of a modern higher educational institution. The updated content of the principles of interaction, norms, traditions and rules of academic staff at the university has become possible thanks to the formation of teams of scientific and pedagogical staff; team spirit and systemic thinking formation, the desire for academic staff self-education activation.

Let's take a look at the phenomena "team", "teamwork", "team interaction", "team interaction competence of a future university teacher".

A profound analysis of scientific literature has shown that in modern science the team is considered by scholars ambiguously. It is defined as a group of people who complement and replace each other in achieving their goals (V. Avdeev [13], G. Lopatenkov [31]). A team is a collective entity of activities, the essence of which is the ability 
to act as a whole, presenting team goals and values, actions, attitudes and behavior (V. Okuniova [11]); a small number of people who share goals, values, different approaches to implement joint activities, common and individual affiliation to a group (E. Salas, R. Berd, S. Tannenbaum [18]). A team is considered to be a group of people who have common goals, complementary skills and abilities, a high level of interdependence of its members, who share responsibility for achieving the final results (T. Galkina [10]); a small number of people who have complementary skills and are united to solve tasks together to increase work efficiency through which they maintain mutual responsibility (A. Kariakin [4]). To add more, a team is a group of two or more individuals who, to achieve a certain goal, coordinate their interactions and labor efforts, are united not only by job regulations but also by the norms of a higher order: goals, values, their own system of communication and motivation (A. Molchanova [32]). A team is a small group, which is characterized by a positive synergy of strong activities focused on solving team tasks (V. Horbunova [6]). So, this means that teams are characterized by internal self-organization, which is mainly based on informal relationships and can add some "chaos" to a wellthought-out team action strategy. Scholars emphasize the complementarity, mutual help of team members who are able to perform any internal group roles and take responsibility for the final results of their joint activities.

Indeed, the team is a group entity, the leading feature of which is the positive synergy of strong activities focused on solving team problems; competence of all team members; role advisability and mutually distributed responsibility, and comfortable interpersonal relations. Team members must have an awareness of the targeted goals of team activities (the overall goal of team activities should be closely reconciled with their own needs, the interests of the team members). That is, the overall goal of team members should be accepted at the motivational level; they must clearly adhere: to the principles of interaction among team members to achieve goals, the established role structure of the team, positions and functions of the leader; have the ability to self-reflection and self-knowledge acquisition, which ensures the development of a sense of belonginess to the team, unity with it and the formation of the image of "We".

In light of the above, we understand the phenomenon of "team" as a group of people organized for a specific purpose who understand the interdependence and the need for interaction and cooperation. Team members should focus on joint, efficient and creative activities and be able to combine individual ideas and experience of each to make rational decisions and achieve common goal.

Another important finding in the understanding of the significant variety of forms and types of teams is as follows: natural work groups, self-managing teams, virtual teams [4, p. 28]. Regardless of the type of a team, the efficiency of its functioning is determined by the level of possession of the relevant knowledge, skills and abilities of its members.

Teamwork as a form of organization of mutual activity is aspired to achieve high efficiency of interconnected and interdependent joint activities, based on high professionalism of team members who share team values, goals and mutual responsibility, have certain roles within which they can show their personal skills.

Teamwork as a form of organization of joint activities implies the ability to partnership interaction. According to psychologists, interaction is interpreted as the direct or indirect influence of entities on each one. Such an interaction generates team member mutual connection, and allows organizing and implementing some activities common to the collective entity. Therefore, the essential characteristic of teamwork is interactivity, which is revealed in the exchange of information between team members, ensures the synchronization, coherence of the pace and rhythm of joint activities, which leads to efficient work of the whole team and high dedication of everyone (L. Aksenovska [16], A. Kariakin [4]). The success of partnership is determined by the following factors: conformity of the behavior of the interacting people to the expectations of each other; adequate understanding of the situation and an adequate style of actions inside; the degree of involvement in team interaction of all participants of the process.

The variety of approaches is used to obtain the most efficient result of the teamwork. Problems that arise during teamwork are worked out in detail, decisions are agreed among members of a team; the team roles and functions of each member of the team are clearly distributed, the processes of internal and external team interaction are strictly regulated. As a result, in the process of a team development certain rules of behavior are developed, shared and supported by all participants.

It is clear that the efficiency of the teaching staff activities at the university depends on the level of cohesion and value-oriented unity. This can be achieved through the creation of a pedagogical team, the participants of which are linked by common goals, developed sense of "we", and the values of pedagogical work.

The necessity of teamwork among university teachers is due to the fact that they often face the situations where: the task instruction is not clearly structured; a significant amount of work needs to be done quickly; the performance of a task requires creativity [10, p. 55]; it's necessary to follow the collegial forms of decision-making, which increase motivation and dedication of all team members $[17$, p. 10], etc. Therefore, the university teacher has to possess team interaction skills.

Considering the above, and on the basis of careful studying of numerous scientific achievements of R. Abliazov [1], E. Aleksandrova [33], E. Britton et al [29], V. Horbunova [6], A. Doyle [21], O. Fil [23], L. Fox et al [7], K. Green [24], L. Karamushka [22, 34], S. Marasi [26], E. Salas, D. Reyes and S. Daniel [15], S. Schinko-Fischli [19], K. Shakhmaeva [12],L. Tompson [9], team interaction skills of a future university teacher is understood as $a$ stable, holistic, integrative building of a personality, which reflects understanding of the importance and the value of a teamwork, possession of a system of knowledge as to theoretical, factual and applied nature of a team, the ways in a teamwork, teambuilding technologies, gaining experience of the team interaction, the ability and readiness for 
efficient activities in solving problems within the frame of dialogue communication and partner interaction with others due to a set of team interaction skills, developed social intelligence, and reflexivity.

The university teacher's skills of a team interaction allows a specialist to combining individual ideas and experience of each team member to make a relevant decision and achieve a common goal; demonstrating responsibility and consistency of actions to solve the assigned educational and professional tasks; providing the teacher with self-control of role behavior and clear implementation of the developed rules of team interaction, professional and social demand in all fields of life.

The following structural components of the skills explored are highlighted as follows: motivational and axiological, cognitive, activity-oriented, personal, reflexiveevaluative, as well as a set of the criteria and their indicators.

Motivational and axiological component includes a need for the team work, recognition of the values of team interaction, awareness of the personal significance of the benefits of joint activities.

Cognitive component means the completeness and sustainability of theoretical, factual and applied knowledge covering the values of professional communication, team building and team interaction, the ways of work in a team.

Activity-oriented component determines the level of master's degree students' skills as a future team member and mastering the experience of team activities: to express own thoughts clearly and logically, share information; the skills to carry out the written electronic communication; set goals, structure own time; convince colleagues of the correctness of the decision, supporting thoughts with strong arguments; find non-standard solutions; admit own mistakes; be personally responsible for the results of work; establish efficient interaction among team members; successfully collaborate in virtual environment; achieve mutual understanding of team members, express trust to them; implement technologies to make joint decisions; manage own emotions; avoid and prevent conflicts.

Personal component is revealed in the level of social, intellect and empathy development.

Reflexive-evaluative component means the skills of reflection and behavior correction, which corresponds to team activities.

It's advisable to develop team interaction competence for training of future university teachers during masters' educational and professional programs, in particular "Pedagogy of Higher School" (Specialty 011 - Educational, Pedagogical Sciences). For this purpose, we have worked out the educational technology to develop the team interaction competence of future university teachers for master's degree students' training (figure 1). This technology is based on the following methodological principles: systemic, competency-based, activity-oriented, personalityoriented, participatory and andragogical.

Systemic principle allows considering all components of professional education of master's degree students as a holistic social system. It describes the systemic characteristics of the process of forming target competence of team interaction in organizational, pedagogical and professional aspects, implement the relevant combination of pedagogical tools, forms and methods of teaching. Competencybased principle allows us to consider such a competence of future university teachers' team interaction as a component of their professional competence, highlight the essence and content of competence components; focuses on the connection between the educational process at the university and the requirements of the external environment, strengthening the practical direction of the educational process. Activity-oriented principle focuses on the priority use of active and interactive teaching methods, and the use of knowledge and skills asmeans that contribute to the formation of algorithms of team interaction. Personality-oriented principle defines the student as an entity of educational activities, aims at creating optimal conditions for the comprehensive development of the student's personality, designing individual achievements in the varieties of team interaction by future university teacher (masters). Participatory principle requires the creation of conditions to form the students' ability to work together. Andragogical principle assumes the direction of the educational process to the needs and requests of master's degree students and reliance on the existing subjective experience.

In addition to general pedagogical principles, we consider to single out other teaching principles: the principle of collective work performance, which assumes that each member of a team performs a clearly defined part of the general task; the principle of activities, which requires the active participation of master's degree students in interactive training, creating situations of professional activities, and providing feedback. The principle of mutual enrichment means that team members have the opportunity to exchange information and could enrich their knowledge with new ideas. The principle of humanism, tolerance of subject-subject relations in the systems "teacher - student", "student - student" provides for the motivational direction of the university academic staff members towards the master's degree student - the future colleague; creates a favorable psychological climate in the relationship between a university lecturer and master's students, foreseeing the consequences of each word, look, gesture ("rinum non nocere") - "First of all, do no harm"; recognizes the uniqueness of the personality of each master's student; respects his/her dignity, trust, acceptance of his/her personal goals and requests. The principle of individuality and equality means that each individual is recognized as a unique personality who is equal among others to show his individuality.

The necessary condition to provide the formation of teamwork skills of future university teachers is to actualize the motivational and axiological attitude of master's degree students to team interaction, namely: create a favorable psychological environment, an atmosphere of creativity, trust, mutual understanding, complementarity; create conditions for the development of the need for joint activities, the acquisition of subjective experience of mutual activities; provide the formation of professional skills of a team member for master's students. This task is solved 


\section{CONCEPTUAL STAGE}

The aim: to develop a team interaction competence of future university teachers

Methodological approaches: systemic, competency-based, activity-oriented, personalityoriented, participatory, andragogical
The principles of collective work performance, activities, mutual enrichment, humanism, tolerance of subjectsubject relations in the systems "teacher - student", "student - student", individuality and equality

\section{MOTIVATIONAL AND INCENTIVE STAGE}

Creating an atmosphere of trust, mutual understanding, complementarity, creativity, the success of the team in performing the tasks set; emotional and moral stimulation
Formation of a sense of responsibility among team members for each member action
The emergence of a synergistic effect, compensating knowledge gaps of each team member with the skills of another member

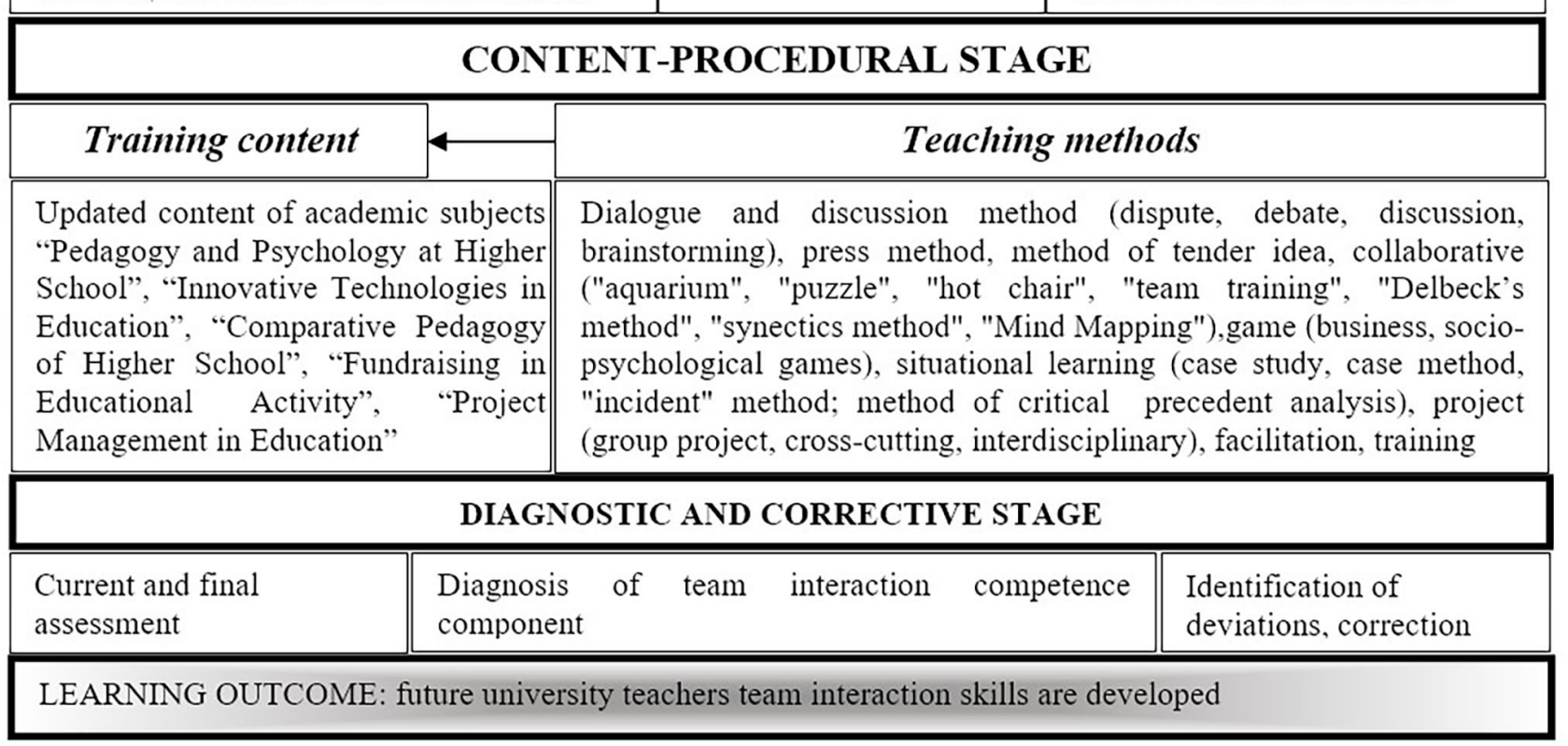

Figure 1. Technology for the development of future university teachers team interaction skills for master's degree students' training

at the motivational and incentive stages of the technology through emotional and moral stimulation; combination of personal interests with team interests; formation of a sense of responsibility among team members for each member actions; appearance of a synergistic effect, when the multiplication of the intellectual efforts of one team member by the efforts of another makes it possible to unite a team to solve problems which are irresistible for one person or a group.

The content and procedural stage of the technology is aimed at the system of knowledge acquisition as to theoretical, factual and applied nature of the team, the advantages and disadvantages of teambuilding, the structure of team roles, the differences between individual and teamwork, the ways of working in a team, team building technologies, and gaining experience of team interaction. This stage provides for theoretical covering of such subjects as "Pedagogy and Psychology of Higher Education", "Innovative
Technologies in Education", "Comparative Pedagogy of Higher Education", "Fundraising in Educational Activities", "Project Management in Education" with learning material focused on the formation of a system of knowledge of a theoretical and empirical nature among master's degree students of the value, significance and the ways of working in a team. The results demonstrate that in the process of studying them there are all possibilities to create the best conditions for the development of master's degree students' team interaction skills through optimization of resources and opportunities in the framework of teaching each subject.

The technology provides for a set of teaching methods and techniques, forms of training organization that contribute to understanding of the essence of team interaction by master's degree students, aimed at their self-analysis as team members, self-determination and self-realization in team activities. 
Now we are focusing on the leading teaching methods and techniques. First of all, these are dialogical and discussion methods of teaching: discussion ("The value of teamwork", "The best tactics and strategies of professional interaction", "Professional roles of a teacher in interaction", "Strategies for preventing and overcoming barriers of professional interaction", "What is the difference between real and virtual teams?"), a dispute ("Technologies of team building and self-development", "Teachers' teamwork in distance learning"), debates ("Teamwork is the path to success", "The team is a professional community of a high level of development, competitive in the labor market", "A team for tasks or tasks for a team? The pros and cons of different types of teams"), brainstorming ("Barriers of professional interaction", "Team leader is ..." [11]), forum "International Pedagogical Conference", dialogue-exchange of impressions, dialogue-discussion, dialogue-conversation, polylogue, "Aquarium", "Take a position", "Life situations", "Circle of ideas", generating ideas method "515"; discussion techniques (proof, argumentation, comparison, alternative); techniques of productive feedback (its descriptive nature and specificity, implementation in the context of the group according to current needs of the team members); empathy techniques (maintaining the conversation, activation of audience perception, fixing attention on the interlocutor, a benevolent attitude towards him and the topic of conversation, paraphrasing, reflecting the speaker's feelings to demonstrate his own interest and understanding, encouragement to continue the statement, summing up the results of the conversation).

The study provides for the use of the "press" method", due to which master's degree students could acquire the experience of a reasoned presentation of their thoughts: "I believe that ..." (position), "Because ..." (justification), "For example ..." (facts and arguments), "So, I think ... "(conclusions), "tender idea method", where teams of master's degree students discuss options to solve the problem on the principle of a "court", "commission", "closed expertise") and etc.

The development of teamwork skills is contributed to the performance of the team presentation by masters in the metaphorical form "My team of like-minded people", which allows them forming an idea of the team's structure and its common goal during the discussion; the ability to delegate authority to team members, distributing roles among team members; general planning of team activities; size of the team. Debating masters have the opportunity to gain knowledge that form the basis of team values and affect joint activities in a team (psychological readiness for joint activities; status, mutual responsibility acceptance by the team members; interconnection and interdependence of team members; mutual understanding, mutual assistance, a sense of teamwork unity, etc.).

The interaction of master's degree students during classes involves the use of various forms: work in dyads; rotational triplets; quadras as to the carousel principle; micro-groups; teams, which members have a common task, during free movement around the classroom and meetings with each other to speak to group members who perform an individual task, etc.

Methods of collaborative learning are appropriate for the development of team interaction competence, namely, "Training in a team", "Puzzle", "Puzzle - 2", "Synectics method", "Delbeke's method", "Hot chair", "Mind Mapping". Such methods' implementation helps master's degree students realize, that success of the team depends on the contribution of each member to the overall solution of the problem [35].

The technology provides for the use of such games: business games - "Invisible thread", "Competition or cooperation", "Squares" (aimed at the active cognition of each other, mutual understanding of communication partners, "co-authorship", in which the experience of cooperation is actively acquired, the development of creative relationships); social and psychological games - "Desert Island", "Shipwreck" (aimed at demonstrating leadership strategies in a group with subsequent internal group discussion and the analysis of the conflict situations).

It's efficient to use the method of situational training case studies, case method, "incident" method; method of critical precedents analysis, which contributes to the development of team interaction skills components.

Attracting master's degree students to project activities "is based on the joint (collective) activities of students aimed at achieving a specific goal ... which adds to the students' activity of an integrated and stimulating nature, forms their skills and ability to work in a team using the division of labor and roles, has an active social direction" [35, p. 266]. They provides them with the acquisition of primary experience in team activities, the consolidation of values and methods of a team to solve the project problems.

M. Bulanova-Toporkova notes that projects can be considered as "active targeted experiment" [36], which allows master's degree students forming the skills of a teamwork and their personal qualities (social intellect, reflection, ability to cooperate and empathy). The technology provides for the use of cross-cutting educational projects covering the entire course of the subject and interdisciplinary projects to implement which one needs to possess knowledge, skills and abilities in a number of academic subjects ("The synergistic effect of team activities", "Conspiracies to see you", "Scientific project", "Educational innovations of the 21 st century", "Professionally important qualities of the teachers' team leader", etc.).

The choice of facilitation methods is due to the fact that they contain the significant opportunities. They increase the efficiency of the group decision-making process (situation analysis; identification of options, alternative solutions; selection of the best option), create and maintain a climate in the group (increase the level of involvement in the discussion process; stimulate initiative; encourage to personal responsibility for the process and result), provide exchange of experience among participants, promote personal development of participants. Within the technology suggested, the following methods will be appropriate: "World Café", "Open Space", "Analysis of Kurt Levin's forces field", "At the same 
time next year", "Search for the future", "Positive change paradigm", "Anti-brainstorming", "Dynamic facilitation" and others [35]. The implementation of these methods ensures the creation of conditions for constructive interaction of master's degree students, the choice of optimal methods, means and forms of interaction, ensuring a favorable moral and psychological climate, resolving and preventing conflict situations of professional interaction.

Now we would like to draw the main attention to the use of the set of trainings. Thus, the training of team interaction is aimed at uniting participants into a single coordinated team to efficiently solve the tasks [37, 38]. During the training, the level of motivation of master's degree students towards cooperation is increasing. One could observe the formation of cohesion, compatibility of general and individual goals of professional activities; awareness and correction of features of role behavior in groups of teachers, increase in the level of positive perception of team members, trust and satisfaction with joint activities, develop a "team spirit" and solidarity, responsibility of everyone in the team, consolidate communication skills. The following exercises can become the basis of such a training [8, p. 73]. They include: introduction, following the rules, acquaintance, expectations, warm-up, reflection and summarizing. During the training we can apply minilectures, work in small groups, discussions, business and role games and various psychological exercises: "Chain" (aimed at forming an idea of the team and its characteristics, when each master's degree student adds his own characteristic to the previous characteristic of the team), "Narrow bridge" (provides the ability to avoid conflicts and find consensus), "Butterfly effect" (allows to form an awareness that the actions of each team member affect the overall result), "Diplomat" (promotes the ability to find consensus and be tolerant to the thoughts of team members).

To add more, the developed trainings ("Corporate culture in a professional educational organization", "We are a team", "Communication and interaction in the teaching team", "Constructive interaction and empathic behavior in conflict", "Communication barriers of a university teacher"), skills and abilities, necessary to ensure teamwork are aimed at optimizing interpersonal relationships in the team, distributing team roles, practicing skills of joint problem solving, training efficient interaction in a conflict situation, improving the psychological climate in a team. The use of trainings should be based on the study of R. Belbin [2], which shows the ability of each team member to play one, often two, and possibly three or even four team roles. At the beginning of the training, it is advisable to discuss the types of roles and their placement in a team (figure 2 [2]).

During the training, master's degree students must try themselves in all known roles, learn about their features, master the skills and abilities to perform certain professional tasks, which appear in the process of formation and development of the "team", realized the importance of teamwork to improve the efficiency of their activities and achievement a common goal and common tasks. We realize that the condition for the emergence of synergy can be the emotional involvement of master's degree students, as well as the optimal structuring of the team and the role distribution of its members. In case of coherence, cooperation of natural features and abilities, goals, needs, feelings, knowledge and attitudes of team members we can expect the effect of emergence, which means the appearance in the team of such features that are absent in individuals who are the members of the team (this effect is denoted by the formula: " $2+2=5 "$ ).

We realize that each created team of masters will be effective if all its members know the goal for which the team was formed, realize the need of a team approach in joint activity, work with maximum effort to achieve high results of team work, perform a specific task to achieve team goals, provide the necessary support, feel personal responsibility for the overall result of the team.

Mandatory reflection of joint activity results involves answering the questions during group discussion: what form of activities is the most efficient? Why? Which activities generate a synergistic effect? How does it arise? or participation in the discussion: "It was important to me...", "I overestimated...", "I remember...", etc.

The basis to implement teamwork skills technology of future university teachers during master's degree students' training were such institutions of higher education: Alfred Nobel University (Dnipro), Kremenchuk Mykhailo Ostrohradskyi National University, Classical Private University (Zaporizhzhyia). The participants of the experiment were master's degree students by the specialty 011 "Educational, Pedagogical Sciences".

The developed technology was carried out for two years (2018-2020 academic years). 154 master's degree students were involved, among whom two groups were formed: experimental -78 people (EG); control -76 people (CG) (where the educational activity of master's degree students was carried out with traditional for higher educational institutions' methods and forms, a separate task to ensure the formation of skills in teamwork implementation was not set).

The results of the dynamics of level indicator changes of the team interaction skills component development for master's degree students of the control and experimental groups are given in table 1 .

The comparison of data of the level of team interaction skills components development for master's degree students of the experimental and control groups indicates the significant positive changes at all the levels that have occurred due to implementing teamwork skills development technology for future university teachers during their master's degree training.

Analyzing the data of the levels of development of the motivational and axiological component of team interaction skills (see table 1), it should be noted that for one and a half years there were some changes in control group, although quite insignificant. Some positive changes were found in master's degree students who had a low level of development of the motivational and axiological component of the skills studied (from 42.1 to $32.9 \%$ ). The similar changes are observed according to the following criteria: cognitive (from 50.0 to $43.5 \%$ ), activities (from 


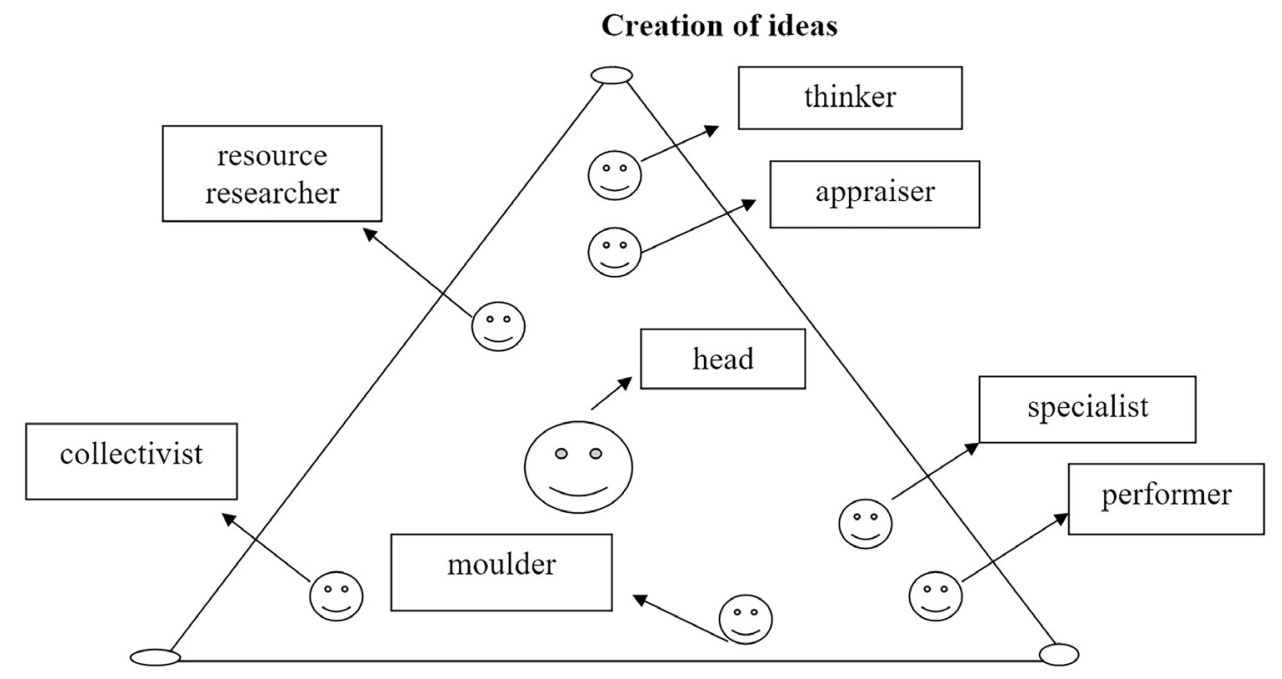

Interaction with people

Completing assignments

Figure 2. Types and placement of each role in a team [2]

Table 1. Dynamics of indicators of teamwork interaction skills components levels for master's degree students of control and experimental groups

\begin{tabular}{|c|c|c|c|c|}
\hline \multirow{4}{*}{ Level } & \multicolumn{4}{|c|}{ Group } \\
\hline & \multicolumn{2}{|c|}{ CG (76 people) } & \multicolumn{2}{|c|}{ EG (78 people) } \\
\hline & \multicolumn{4}{|c|}{ Experiment stage } \\
\hline & Stating & Control & Stating & Control \\
\hline \multicolumn{5}{|c|}{ Team interaction skills component } \\
\hline \multicolumn{5}{|c|}{ Motivational and axiological } \\
\hline High & 19.7 & 23.7 & 20.5 & 37.2 \\
\hline Sufficient & 38.2 & 43.4 & 42.3 & 47.4 \\
\hline Low & 42.1 & 32.9 & 37.2 & 15.4 \\
\hline \multicolumn{5}{|c|}{ Cognitive } \\
\hline High & 23.7 & 26.3 & 24.4 & 37.2 \\
\hline Sufficient & 26.3 & 30.2 & 28.2 & 50.0 \\
\hline Low & 50.0 & 43.5 & 47.4 & 12.8 \\
\hline \multicolumn{5}{|c|}{ Activity } \\
\hline High & 19.8 & 23.7 & 19.2 & 39.7 \\
\hline Sufficient & 36.8 & 48.7 & 32.1 & 44.9 \\
\hline Low & 43.4 & 27.6 & 48.7 & 15.4 \\
\hline \multicolumn{5}{|c|}{ Personal } \\
\hline High & 21.1 & 23.7 & 19.2 & 33.3 \\
\hline Sufficient & 30.2 & 38.2 & 33.3 & 50.0 \\
\hline Low & 48.7 & 38.1 & 47.5 & 16.7 \\
\hline \multicolumn{5}{|c|}{ Reflexive and evaluative } \\
\hline High & 23.7 & 26.3 & 23.1 & 38.5 \\
\hline Sufficient & 43.4 & 50.0 & 47.4 & 52.6 \\
\hline Low & 32.9 & 23.7 & 29.5 & 8.9 \\
\hline
\end{tabular}

43.4 to $27.6 \%$ ), personal (from 48.7 to $38.1 \%$ ), reflexiveevaluative (from 32.9 to $23.7 \%$ ).

According to the results found in EG, it is necessary to note that after the realization of the developed technology there were positive changes. Indicators of the motivational and axiological component were: for a high level $+16.7 \%$, a sufficient level $+5.1 \%$, a low level $-21.8 \%$.

Regarding the dynamics of the levels of development of the cognitive component of team interaction skills, the obtained results indicate the significant positive changes. Thus, the number of master's degree students, whose indicators are referred to a high level, has risen sharply in EG (from 24.4 to $37.2 \%$ ). The growth accounted for $+12.8 \%$. The analysis of the obtained results showed that master's students have knowledge of theoretical, factual and applied nature of the team, the advantages and disadvantages of teams, the role structure of teams, the differences between individual work and teamwork, the ways of working in a team, technologies of team building, gaining experience of team interaction. We can emphasize that the number of low-level masters has significantly decreased (from 47.4 to $12.8 \%$ ). The growth amounted to 34.6. Comparing the data with control group, we have to note that there are some changes, but insignificant: high level - from 23.7 to $26.3 \%$, sufficient - from 26.3 to $30.2 \%$, low - from 50.0 to $43.5 \%$. The indicators' growth amounted to: $+2.6 \%$; $+3.9 \% ;-6.5 \%$.

The significant changes could be observed at the level of development of the activity component. Thus, in CG the number of master's students with a high level is $23.7 \%$ (compared to $19.8 \%$ ), in EG - 39.7\% (compared to $19.2 \%$ ). The growth accounts for +3.9 and +20.5 . As for the low level of development of the component under invastigation, the EG growth was $33.3 \%$ (in control $-15.8 \%)$ ). The obtained results indicate the efficiency of the chosen methods and forms of education, due to the implementation of which the master's students have developed the ability to clearly and logically express their thoughts, to convey information; have written electronic communication skills; set goals, structure own time; convince colleagues of the correctness of decision, confirming 
Table 2. Dynamics of levels indicators of teamwork interaction skills development for master's degree students of control and experimental groups

\begin{tabular}{|c|c|c|c|c|}
\hline \multirow{4}{*}{ Level } & \multicolumn{4}{|c|}{ Group } \\
\hline & \multicolumn{2}{|c|}{ CG (76 people) } & \multicolumn{2}{|c|}{ EG (78 people) } \\
\hline & \multicolumn{4}{|c|}{ Experiment stage } \\
\hline & Stating & Control & Stating & Control \\
\hline High & 21,6 & 24,7 & 21,3 & 37,2 \\
\hline Sufficient & 35,0 & 42,1 & 36,7 & 49,0 \\
\hline Low & 43,4 & 33,2 & 42,0 & 13,8 \\
\hline
\end{tabular}

their opinions with strong arguments; find non-standard solutions; admit own mistakes; be personally responsible for the results of the work; establish efficient interaction of team members; are able to successfully cooperate in a virtual environment; reach mutual understanding, achieve mutual understanding and coherence of team members; implement technologies of joint decision-making; manage own emotions; avoid and prevent conflicts.

Personal component indicators have also changed significantly. In EG, positive changes were observed at all levels: high level - from 19.2 to $33.3 \%$, sufficient level from 33.3 to $50.0 \%$, low level - from 47.5 to $17.2 \%$. Master's students of CG showed insignificant positive changes at the level of development of this component: high level - from 21.1 to $23.7 \%$ (growth $+2.6 \%$ ); sufficient level from 30.2 to $38.2 \%$ (growth $+8 \%$ ); low level - from 48.7 to $38.1 \%$ (growth $-10.6 \%$ ).

The diagnosis of the reflexive and evaluative component showed that in EG after having implemented the technology $38.5 \%$ of master's students showed a high level of mastery of reflection skills, correction of behavior that corresponds to teamwork, which is $15.4 \%$ more than in the primary diagnosis. The number of low-level masters decreased by $20.6 \%$. Changes in the control group are as follows: high $+2.6 \%$, sufficient $+6.6 \%$, low $-9.2 \%$.

At the end of the formation stage of the experiment, the study was conducted aimed at determining the dynamics of levels of skills development in the team interaction of master's students of two groups (table 2).

Comparing the results obtained at the control stage of the experiment, we have to state that implementing teamwork interaction skills development for future university teachers during master's degree training led to a sharp increase of the number of master's students, which is attributed to high and sufficient levels of skills.

\section{Conclusions and prospects for further research}

Currently, the incorporation of teamwork into the educational process became a very important approach in enhancing the pedagogical courses at higher educational institutions, as this approach formulates a very beneficial means of interaction with the global challenges in the profession of a teacher.

Having concluded our theoretical analysis, Master's degree students' experiment and having compared and contrasted data obtained, the results of the study demonstrate the following: the labor market today requires a specialist who could combine individual ideas and experience of each team member to make a relevant decision and achieve a common goal; demonstrate responsibility and consistency of actions to solve the assigned educational and professional tasks; provide the teacher with selfcontrol of role behavior and clear implementation of the developed rules of team interaction, professional and social demand in all fields of life.

The findings of the study are supported by the fact that in addition to professional knowledge and skills, a future university teacher must have a system of teambuilding skills. Developing such skills is not a bargain, but an objective requirement of the labor market. The high school should respond to these requests.

Results provide the basis to distinguish the structural components of the skills explored: motivational and axiological, cognitive, activity-oriented, personal, reflexiveevaluative, as well as a set of the criteria and their indicators. The worked out educational technology to develop the team building competence of future university teachers for Master's degree students is based on the following methodological principles: systemic, competency-based, activity-oriented, personality-oriented, participatory and andragogical.

The acquisition of basic knowledge as to theoretical, factual and applied nature of the team, the advantages and disadvantages of teambuilding, the structure of team roles, the differences between individual and teamwork, the ways of working in a team, team building technologies, gaining experience of team interaction and mastering the basic teambuilding skills for Master's degree students in the specialty 011 Educational, Pedagogical sciences was facilitated by the following courses: "Pedagogy and Psychology of Higher Education", "Innovative Technologies in Education", "Comparative Pedagogy of Higher Education", "Fundraising in Educational Activities", "Project Management in Education".

The technology provides for a set of teaching methods and techniques, forms of training organization that contribute to understanding of the essence of team interaction by Master's degree students, aimed at their self-analysis as team members, self-determination and self-realization in team activities.

Through the implementation of dialogical and discussion methods of teaching using game teaching methods involving modeling of professional situations, joint analysis and problem solving, our results can demonstrate the ability of Master's degree students to reflect on their own experience and individual characteristics necessary to develop teambuilding skills.

The interaction of Master's degree students during classes involves the use of various forms: work in dyads; rotational triplets; quadras as to the carousel principle; micro-groups; teams, which members have a common task, during free movement around the classroom and meetings with each other to speak to group members who perform an individual task, etc. 
To develop team interaction competence in Master's degree students of pedagogical university it is appropriate to use the method collaborative learning ("Training in a team", "Puzzle", "Puzzle - 2", "Synectics method", "Delbeke's method", "Hot chair", "Mind Mapping") and some facilitation methods (World Cafe, Open Space, Kurt Levin Force Field Analysis, Anti-Brainstorming, Dynamic Facilitation).

Superior results could be seen for some more pedagogical techniques, namely: method of situational training and project work, which involves the need of a team approach in joint activity, work with maximum effort to achieve high results of team work, perform a specific task to achieve team goals, provide the necessary support, feel personal responsibility for the overall result of the team.

The implementation of interactive teaching methods was aimed at the development of teambuilding skills in Master's degree students. But in order to successfully develop the ability to apply these skills in professional pedagogical situations, Master's degree students must practice them throughout their studies, as these skills tend to reverse.

Teaching teamwork skills in the education pedagogy will help master's degree students for better learning and will have many positives in developing the students' potentials and skills that are needed to confront the present and future challenges of the teacher profession. The methodology of incorporating teamwork into pedagogy is based on major strategies including: setting general teaching strategies; designing teamwork; organizing teamwork; and evaluating teamwork.

This new proposed guiding tool is recommended to be used by pedagogical universities as a means for managing a successful teamwork in pedagogical environment. Summing up, we should note that the use of technology of teambuilding skills development for future university teachers during master's degree training is quite efficient. It is a perspective problem for research in the future and could be studied at different levels of both components the skills in the implementation of teamwork for students of different major and the phenomenon as a whole.

\section{References}

[1] R. Abliazov, Komandnyi menedzhment (Team management) (Professional, Kiev, 2008)

[2] R. Belbin, Tipy rolei $v$ komandakh menedzherov (Types of roles in management teams) (NIRRO, Moscow, 2003)

[3] A. Ivlev, Razvitie studencheskoi komandy v obrazovatelnom protsesse vuza (Development of the student team in the educational process of the university)

[4] A. Kariakin, Komandnaia rabota: osnovy teorii $i$ praktiki (Teamwork: Foundations of Theory and Practice) (Ivanovo State Power Engineering University, Ivanovo, 2003)

[5] D. Shakirova, Obrazovatelnye tekhnologii i obshestvo 9, 306 (2006)
[6] V. Horbunova, Psykholohiia komandoutvorennia: tsinnisno-rolovyi pidkhid do formuvannia ta rozvytku komand (Psychology of team building: Value-role approach to the formation and development of teams) (Zhytomyr State University named after Ivan Franko, Zhytomyr, 2014)

[7] L. Fox, R. Onders, C.J. Hermansen-Kobulnicky, T.N. Nguyen, L. Myran, B. Linn, J. Hornecker, Journal of Interprofessional Care 32, 127 (2018)

[8] G. Satran, Trening komandoobrazovaniia (Team building training) (Rech, St. Petersburg, 2005)

[9] L.L. Thompson, M. Thompson, Making the team: A guide for managers (Pearson/Prentice Hall, 2008)

[10] T. Galkina, Sotsiologiia upravleniia: ot gruppy $k$ komande (Sociology of management: from group to team) (Finance and statistics, Moscow, 2003)

[11] V. Okuneva, Modern problems of science and education (2013)

[12] K. Shakhmaeva, L. Savva, Modern problems of science and education (2017)

[13] V. Avdeev, Upravlenie personalom: tekhnologiya formirovaniya komandy (Personnel management: technology of team building) (Sphere, Moscow, 2008)

[14] A. Panfilova, Mozgovye shturmy v kollektivnom priniatii reshenii (Brainstorming in collective decision making) (Flinta, Moscow, 2007)

[15] E. Salas, D. Reyes, S. McDaniel, American Psychologist 73, 593 (2018)

[16] L. Aksenovskaia, Ordernaia model orhanizatsionnoi kultury (Order model of organizational culture) (Academic Project, Moscow, 2007)

[17] A. Horbovyi, Scientific Bulletin of Volyn National University named after Lesya Ukrainka pp. 54-59 (2009)

[18] S.I. Tannenbaum, R.L. Beard, E. Salas, in Issues, Theory, and Research in Industrial/Organizational Psychology, edited by K. Kelley (North-Holland, 1992), Vol. 82 of Advances in Psychology, pp. 117153

[19] S. Schinko-Fischli, Applied Improvisation for Coaches and Leaders: A Practical Guide for Creative Collaboration (Routledge, N.Y., 2019)

[20] P. Lau, T. Kwong, K. Chong, E. Wong, International Journal for Lesson and Learning Studies 3, 80 (2014)

[21] A. Doyle, Important team building skills that employers value (2020), https://thebalancecareers.com/ list-of-team-building-skills-2063772

[22] L. Karamushka, Psykholohiia osvitnoho menedzhmentu (Psychology of educational management) (Lybid, Kiev, 2004)

[23] O. Fil, Formuvannia psykholohichnoi hotovnosti personal osvitnikh orhanizatsii do roboty $v$ konkurentozdatnii upravlinskii komandi (Formation of students' ability to work in a team in the process of training bank specialists)

[24] K. Greene, The English Journal 106, 13 (2016) 
[25] M. Loughry, M. Ohland, D. Woehr, Journal of Marketing Education 36, 5 (2014)

[26] S. Marasi, Organization Management Journal 16, 324 (2019)

[27] B. Sairam, C. Sirisuthi, K. Wisetrinthong, International Education Studies 10, 143 (2017)

[28] X. Zhuang, C. MacCann, L. Wang, L. Liu, R.D. Roberts, ETS Research Report Series 2008, i (2008)

[29] E. Britton, N. Simper, A. Leger, J. Stephenson, Assessment and Evaluation in Higher Education 42, 378 (2017)

[30] C. Chakraborty, A.R. Sharma, G. Sharma, M. Bhattacharya, R.P. Saha, S.S. Lee, Archives of Medical Research 51, 728 (2020)

[31] G. Lopatenkov, Formirovanie u studentov umeniia $k$ rabote $v$ komande $v$ protsesse podgotovki bankovskikh spetsialistov (Formation of students' ability to work in a team in the process of training bank specialists)

[32] A. Molchanova, Orhanizatsiina povedinka (Organizational behavior) (Lileia-NV, Ivano-Frankivsk, 2015)

[33] E. Aleksandrova, Pedagogicheskie komandy kak sredstvo aktivizatsii innovatsionnoi deiatelnosti obrazovatelnykh ucherezhdenii (Teaching teams as a means of enhancing the innovative activities of educational institutions)

[34] L. Karamushka, O. Fil, Formuvannia konkurentnozdatnoi upravlinskoi komandy (na materiali diialnosti osvitnikh orhanizatsii) (Formation of a competitive management team (based on the activities of educational organizations)) (INKOS, Kiev, 2007)

[35] N. Volkova, Interaktyvni tekhnolohii navchannia u vyshchii shkol. (Interactive learning technologies in high school) (Alfred Nobel University, Dnipro, 2018)

[36] M. Bulanova-Toporkova, Pedagogika i psikhologiia vysshei shkoly (Higher education pedagogy and psychology) (Feniks, Rostov-on-Don, 2006)

[37] N. Volkova, A. Tokarieva, M. Karpova, Training as an effective way to develop the future pediatricians' readiness to work in a team, https: //www.researchgate.net/publication/ 341509960_Training_as_an_effective_way_ to_develop_the_future_paediatricians\%27_ readiness_to_work_in_a_team

[38] N. Volkova, N. Zinukova, K. Vlasenko, T. Korobeinikova, SHS Web of Conferences 75, 04002 (2020) 